\title{
2 10 \\ Thermodynamics of the Conversion of \\ Plutonium Dioxide to Plutonium Monocarbide
}

Theodore M. Besmann

Terrence B. Lindemer 


\section{DISCLAIMER}

This report was prepared as an account of work sponsored by an agency of the United States Government. Neither the United States Government nor any agency Thereof, nor any of their employees, makes any warranty, express or implied, or assumes any legal liability or responsibility for the accuracy, completeness, or usefulness of any information, apparatus, product, or process disclosed, or represents that its use would not infringe privately owned rights. Reference herein to any specific commercial product, process, or service by trade name, trademark, manufacturer, or otherwise does not necessarily constitute or imply its endorsement, recommendation, or favoring by the United States Government or any agency thereof. The views and opinions of authors expressed herein do not necessarily state or reflect those of the United States Government or any agency thereof. 


\section{DISCLAIMER}

Portions of this document may be illegible in electronic image products. Images are produced from the best available original document. 
Printed in the United States of America: Available from

National Technical Information Service

U.S. Department of Commerce

5285 Port Royal Road, Springfield, Virginia 22161

Price: Printed Copy $\$ 4.00$; Microfiche $\$ 2.25$

This report was prepared as an account of work sponsored by the United States Government. Neither the United States nor the Energy Research and Development Administration/United States Nuclear Regulatory Commission, nor any of their employees, nor any of their contractors, subcontractors, or their employees, makes any warranty, express or implied, or assumes any legal liability or responsibility for the accuracy, completeness or usefulness of any information, apparatus, product or process disclosed, or represents that its use would not infringe privately owned rights. 
Contract No. W-7405-eng-26

CHEMICAL TECHNOLOGY DIVISION

THERMODYNAMICS OF THE CONVERSION OF PLUTONIUM DIOXIDE TO

PLUTONIUM MONOCARBIDE

Theodore M. Besmann and Terrence B. Lindemer

Submitted for publication in the Journal of Nuclear Materials

JULY 1976

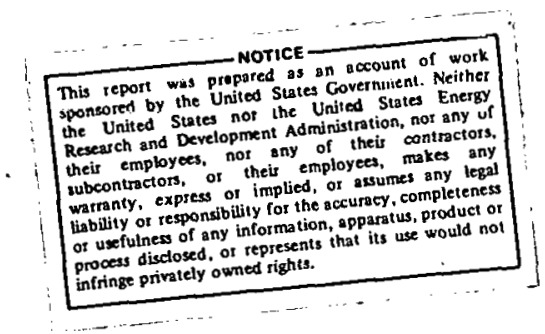

OAK RIDGE NATIONAL LABORATORY

Oak Ridge, Tennessee 37830

operated by

UNION CARBIDE CORPORATION

for the

ENERGY RESEARCH AND DEVELOPMENT ADMTIISTRATION 
THIS PAGE

\section{WAS INTENTIONALLY LEFT BLANK}


TABLE OF CONTENTS

$\underline{\text { Page }}$

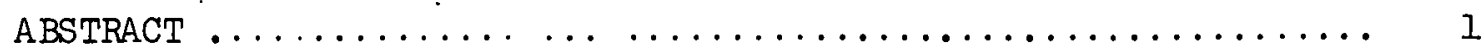

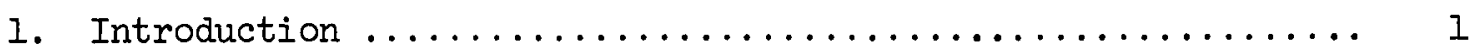

2. Phase Relations in the Pu-C-O System $\ldots \ldots \ldots \ldots \ldots \ldots \ldots \ldots$

3. Equilibrium Thermodynamic Analysis ................ 4

3.1 Phase Field $\mathrm{PuO}_{2-\mathrm{x}}+\mathrm{C} \ldots \ldots \ldots \ldots \ldots \ldots \ldots \ldots \ldots \ldots \ldots$

3.2 Phase Field $\mathrm{PuO}_{1.61}+\mathrm{PuO}_{1.5}+\mathrm{C} \ldots \ldots \ldots \ldots \ldots \ldots \ldots \ldots+7$

3.3 Phase Field $\mathrm{PuO}_{1.5}+\mathrm{PuC}_{1.5}+\mathrm{C} \ldots \ldots \ldots \ldots \ldots \ldots \ldots \ldots$

3.4 Phase Field $\mathrm{PuO}_{1.5}+\mathrm{PuC}_{1-\mathrm{x}} \mathrm{O}+\mathrm{PuC}_{1.5} \ldots \ldots \ldots \ldots \ldots \ldots 9$

3.5 Phase Fields $\mathrm{PuO}_{1.5}+\mathrm{PuC}_{1-\mathrm{x}} \mathrm{O}_{\mathrm{x}}$ and $\mathrm{PuC}_{1.5}+\mathrm{PuC}_{1-\mathrm{x}} \mathrm{O}_{\mathrm{x}} \ldots 12$

4. Assessment of Direct Carbothermic Reduction ............. 14

5. Assessment of Two-step Reduction ................ 16

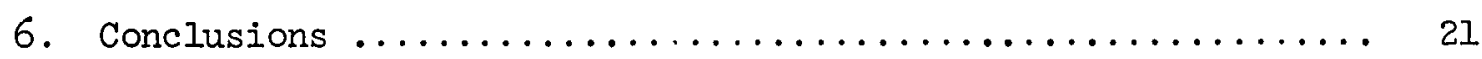

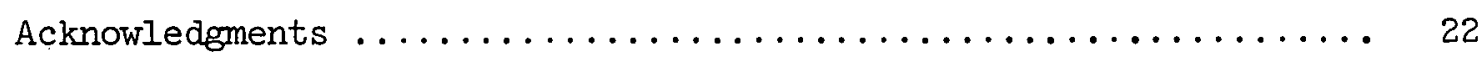

Appendix: Calculated Equilibrium Partial Pressures ......... 23

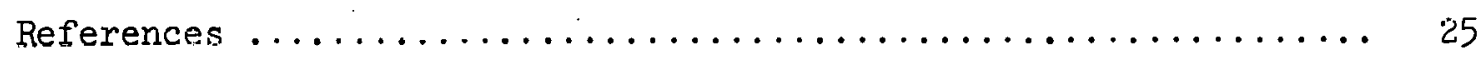




\title{
THERMODYNAMICS OF THE CONVERSION OF PLUTONIUM DIOXIDE TO PLUTONIUM MONOCARBIDE*
}

\author{
Theodore M. Besmann and Terrence B. Lindemer \\ Chemical Technology Division \\ Oak Ridge National Laboratory \\ Oak Ridge, Tennessee 37830
}

\begin{abstract}
The present study contains an equilibrium thermodynamic analysis of the Pu-C-O system and a discussion from an equilibrium thermodynamic point of view of the direct carbothermic reduction and two-step carbothermichydrogen reduction of $\mathrm{PuO}_{2}$ to $\mathrm{PuC}_{1-\mathrm{x}}$. Included are considerations of the partial pressures of the various species in the Pu-C-O and Pu-C-H systems, the process parameters required for conversion of the oxide to the carbide, and the loss of plutonium due to vapor species.
\end{abstract}

\section{Introduction}

The recently renewed interest in advanced nuclear fuels has resulted in the consideration of the monocarbide of plutonium as a fuel component. The primary means of production investigated to date has been the carbothermic reduction of $\mathrm{PuO}_{2}$ either in vacuum or flowing inert gas. Disagreement exists, however, as to whether carbothermic reduction can actually yield sufficiently oxygen-free monocarbide.

\footnotetext{
* Research sponsored by the Energy Research and Development Administration under contract with Union Carbide Corporation.
} 
Several researchers have reported experimental efforts to prepare plutonium monocarbide [1-4]. Only Potter [5], however, has attempted a relatively complete thermodynamic analysis of the carbothermic reduction process. As an alternative, Sowden et al. [6] have reported a preliminary investigation of a two-step process involving carbothermic reduction of the oxide to the sesquicarbide followed by hydrogen stripping of carbon to produce the monocarbide. This process may dvoid the difficulties of direct carbothermic reduction.

It is the object of the present study to perform a thermodynamic analysis similar to that of Potter's [5] using the most recent thermodynamic data. Additionally, the effect of temperature on the Pu-C-O system will be investigated and the two-step reduction process analyzed.

2. Phase Relations in the Pu-C-O System

Potter [5] has reviewed the phase relations in the Pu-C-O system and has developed a phase diagram for $1570 \mathrm{~K}$ (fig. 1).* An independent evaluation of the phase relations performed for the present study using the equilibrium calculations described below indicates agreement with his diagram.

An interesting feature of the Pu-C-O system is that the plutonium monocarbide phase requires carbon-site vacancies for stability such that the maximum homogeneity range of $\mathrm{PuC}_{I-\mathrm{X}}$ is $0.64 \leq \mathrm{x} \leq 0.94$ at $907 \mathrm{~K}$ [7]. Potter [5] notes that $a \cdot \mathrm{PuC}_{\mathrm{x}} \mathrm{O}_{\mathrm{y}}$ solid solution (plutonium monoxycarbide) exists as a result of oxygen substituting for carbon in the monocarbide.

\footnotetext{
* The following notation is used throughout: <> pure element or compound in the solid state; [ ] solid solution (subscript denotes solvent); \{\} liquid state; ( ) gaseous state.
} 


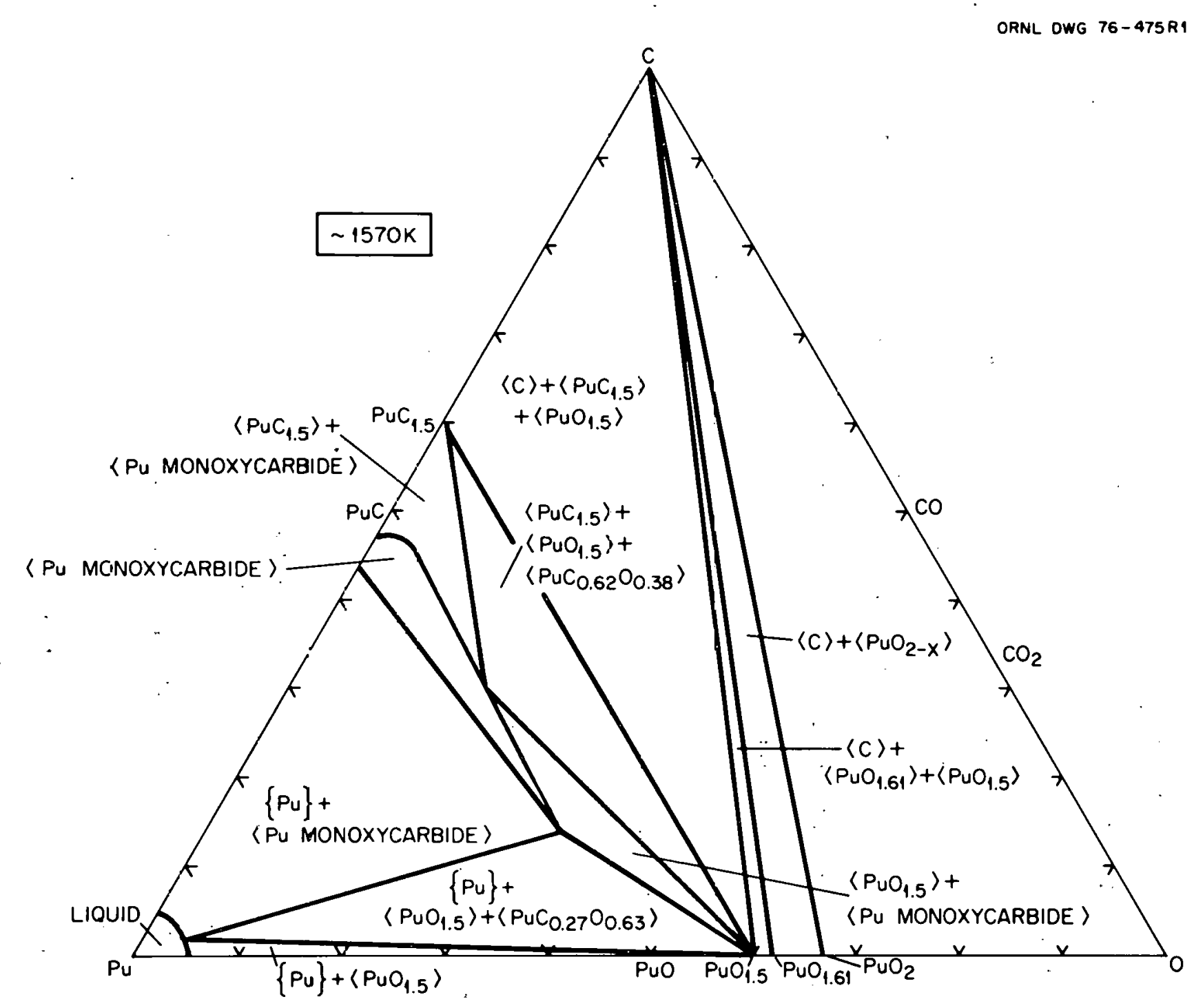

Fig. 1. Ternary phase diagram for the Pu-C-O system at $\sim 1570 \mathrm{~K}$ after Potter [5]. 
A similar phase is found in the U-C-O system, although the maximum oxygen substitution in the Pu-C-O system is 67 at. \% as opposed to 34 at. \% for uranium monoxycarbide [8].

Reaction paths for the carbothermic reduction of $\mathrm{PuO}_{2}$ to the monocarbide have been postulated by Skavdahl [2] and Yahata and Ouchi [4]. Skavdahl [2] notes that the dioxide can react with carbon to form $\mathrm{PuC}_{1.5}$, $\mathrm{PuO}_{1.5}$, and $\mathrm{PuC}_{\mathrm{x}} \mathrm{O}_{\mathrm{y}}$, thus liberating $\mathrm{CO}$ gas during the reduction. Yahata and Ouchi [4] also observed these phases, but they suggest that $\mathrm{PuO}_{2-\mathrm{x}}$ may be present as a nonequilibrium intermediate phase. The regions of the phase diagram in fig. I which must be considered in an equilibrium thermodynamic analysis are:

$$
\begin{aligned}
& \mathrm{PuO}_{2-\mathrm{x}}+\mathrm{C} \\
& \mathrm{PuO}_{1.61}+\mathrm{PuO}_{1.5}+\mathrm{C} \\
& \mathrm{PuO}_{1.5}+\mathrm{PuC}_{1.5}+\mathrm{C} \\
& \mathrm{PuO}_{1.5}+\mathrm{PuC}_{\mathrm{x}} \mathrm{O}_{y}+\mathrm{PuC}_{1.5} \\
& \mathrm{PuC}_{x} \mathrm{O}_{y}+\mathrm{PuO}_{1.5} \\
& \mathrm{FuC}_{x y} \mathrm{O}_{y}+\mathrm{PuC}_{1.5^{\circ}}
\end{aligned}
$$

\section{Equilibrium Thermodynamic Analysis}

The feasibility of the carbothermic reduction of $\mathrm{PuO}_{2}$ to $\mathrm{PuC}_{1-\mathrm{x}}$ is ultimately governed by the thermodynamic equilibrium composition of the system, i.e., the composition in the absence of any limiting effects (chemical kinetic or mass transport). The equilibrium composition is found by computing the equilibrium partial pressures for the gaseous species over the appropriate regions of the $\mathrm{Pu}-\mathrm{C}-\mathrm{O}$ phase diagram. It is the partial pressure of $\mathrm{CO}$ which is of greatest importance since the evolution of $\mathrm{CO}$ gas is the primary reduction mechanism. The partial 
pressures of other possibly important species must be known, however, since a high partial pressure of another species, such as plutonium, may result in a change in the composition of the condensed phases.

The equilibrium composition in each of the condensed phase regions listed above was computed using the method of direct minimization of the system free energy outlined by Eriksson [9]. A general computer program, SOLGAS, developed by him and modified for more convenient use with the type of systems considered here was used to perform the calculations. Several manual calculations were also performed to insure the validity of the machine calculations. Table 1 includes the thermodynamic values for all the species considered. The data have been obtained from the most recent and reliable reported values of the thermodynamic properties of the various species. These values are used throughout the equilibrium calculations. The inclusion of the relatively large number of gaseous species was for the purpose of insuring that no possibly important species would be omitted.

\section{I Phase Field $\mathrm{PuO}_{2-\mathrm{x}}+\mathrm{C}$}

In the $\mathrm{PuO}_{2-\mathrm{x}}+\mathrm{C}$ phase region where $0.0 \leq \mathrm{x} \leq 0.39$, the equilibrium CO partial pressure is both a function of tempcrature and $x$ [17]. Al $\mathrm{T} \geq 1600 \mathrm{~K}, \mathrm{p}_{\mathrm{CO}}$ is greater than 0.02 atm $(0.002 \mathrm{MPa})$, and the partial pressures of any plutonium-bearing species are several orders of magnitude below $\mathrm{p}_{\mathrm{CO}}$. Under these conditions, the $\mathrm{CO}$ evolution rate at equilibrium will be much higher than in the other regions of the phase diagram listed above, and the rate of plutonium evaporation will be much lower. As a result, the carbothermic reduction of $\mathrm{PuO}_{2-\mathrm{x}}$ to $\mathrm{PuO}_{1.61}$ is not believed to be limiting the reduction process to produce $\mathrm{PuC}_{1-\mathrm{x}}$ and will not be considered in dctail here. 
Table 1

Thermodynamic Values

\begin{tabular}{|c|c|c|c|c|c|c|}
\hline \multirow[b]{2}{*}{ Species } & \multirow{2}{*}{$\begin{array}{c}\text { Temperature } \\
(\mathrm{K})\end{array}$} & \multicolumn{2}{|c|}{$\Delta \mathrm{H}_{\mathrm{f}}^{\mathrm{O}}$} & \multicolumn{2}{|c|}{$\Delta S_{f}^{?}$} & \multirow[b]{2}{*}{ Reference } \\
\hline & & $\overline{\mathrm{kcal} / \mathrm{mol}}$ & $(\mathrm{kJ} / \mathrm{mol})$ & eu $(\mathrm{J} / \mathrm{r}$ & nol - K & \\
\hline \multicolumn{7}{|c|}{ Carbothermic reduction of $\mathrm{PuO}_{2}$ to $\mathrm{PuC}_{0.88}$} \\
\hline$(c 0)$ & 1800 & -28.032 & $(-1.17 .29)$ & 2n. 17 & $(84.39)$ & [10] \\
\hline$\left(\mathrm{Lu}_{2}\right)$ & 1800 & كو6. الو & $(-3 \div 6.7 ?)$ & 0.030 & $(0.13)$ & {$[10]$} \\
\hline$(0)$ & 1800 & 59.55 & $(249.2)$ & 15.93 & $(66.65)$ & [II] \\
\hline (Pu) & 1800 & 78.11 & $(326.8)$ & 21.23 & $(88.83)$ & [12] \\
\hline (Puo) & $1600-2.150$ & -28.5 & $(-119)$ & 9.7 & $(41)$ & [13] \\
\hline$\left(\mathrm{FuO}_{2}\right)$ & $1600-2150$ & -112.6 & $(-471.1)$ & -6.6 & $(-28)$ & [13] \\
\hline$\left(\mathrm{PuC}_{2}\right)$ & 1800 & 136 & $(509)$ & 50 & $(210)$ & $*$ \\
\hline$\left\langle\mathrm{PuO}_{1.5}\right\rangle$ & $1600-2150$ & -199.8 & $(-836.0)$ & -31.90 & $(133.5)$ & [13] \\
\hline$\left.<\mathrm{PuO}_{1.61}\right\rangle$ & $1600-2150$ & -210 & $(-879)$ & -33.0 & $(-138)$ & [13] \\
\hline$<\operatorname{PuC}_{0.88}>$ & 1800 & -7.77 & $(-32.5)$ & $2.94^{* *}$ & $(12 \cdot 3)$ & {$[16]$} \\
\hline$<\mathrm{PuC}_{1.5}>$ & 1800 & -19.63 & $(-82.13)$ & $-0.936^{x-x}$ & $(-3.97)$ & [16] \\
\hline
\end{tabular}

Hydrogen reduction of $\mathrm{PuC}_{1.5}$ to $\mathrm{PuC}_{0.88}$

\begin{tabular}{lllllll}
$(\mathrm{H})$ & 1300 & 53.5 & $(22.4)$ & 13.89 & $(58.12)$ & {$[1]_{3}^{j}$} \\
$\left(\mathrm{CH}_{4}\right)$ & 1300 & -21.971 & $(-91.929)$ & -26.54 & $(-111.0)$ & {$[10]$} \\
$\left(\mathrm{C}_{2} \mathrm{H}_{2}\right)$ & 1300 & 53.128 & $(222.29)$ & 12.63 & $(52.85)$ & {$[10]$} \\
$(\mathrm{Pu})$ & 1300 & 78.01 & $(32.64)$ & 21.18 & $(88.62)$ & {$[12]$} \\
$\left(\mathrm{Pur},{ }_{1}\right)$ & 1600 & 136 & $(569)$ & 54.3 & $(190)$ & $*$ \\
$\left\langle\mathrm{PuC}_{0.88}\right\rangle$ & 1300 & -12.93 & $(-54.10)$ & $-0.328^{*-*}$ & $(-1.37)$ & {$[16]$} \\
$\left\langle\mathrm{PuC}_{1.5}\right\rangle$ & 1300 & -21.37 & $(-89.41)$ & $-2.06^{* *}$ & $(-8.62)$ & {$[16]$} \\
\hline
\end{tabular}

* Calculated from the fef $f^{\circ}$ of Faircloth et al. [14] and the $\Delta \mathrm{H}_{\mathrm{f}}^{\circ}$ and $\mathrm{S}_{2,98}^{\mathrm{O}}$ of Schumm et al. [15] for the analogous species $\mathrm{CeC}_{2}$. ** Calculated from respective $\mathrm{S}_{\mathrm{T}}^{\circ}$ for $\mathrm{PuC}_{0.88}$ and $\mathrm{PuC}_{1.5}[16]$, and $\mathrm{S}_{\mathrm{T}}^{\circ}$ for plutonium
[12] and carbon [11]. 
3.2 Phase Field $\mathrm{PuO}_{1.61}+\mathrm{PuO}_{1.5}+\mathrm{C}$

Eight gaseous species ( $\mathrm{CO}, \mathrm{CO}_{2}, \mathrm{O}, \mathrm{O}_{2}, \mathrm{Pu}, \mathrm{PuO}, \mathrm{PuO}_{2}$, and $\mathrm{PuC}_{2}$ ) were included in the equilibrium calculations. Only the species CO, Pu, and PuO were found to have significant partial pressures. These are plotted versus temperature in fig. 2 for three phase fields, including the $\mathrm{PuO}_{1.61}+\mathrm{PuO}_{1.5}+\mathrm{C}$ field. Potter [5] has made similar calculations of the equilibrium Co partial pressure in this phase field, and his results agree closely with those reported here. Such agreement should be expected, however, since the thermodynamic data used in the respective analyses. differ only slightly.

Pickles [8] has reported CO vapor pressure measurements over $\mathrm{PuO}_{1.61}+$ $\mathrm{PuO}_{1.5}+\mathrm{C}$, although in his reaction (10), he incorrectly indicates that $\mathrm{PuO}_{2}$ reacts with $\mathrm{C}$ to form $\mathrm{PuO}_{1.5}$ and $\mathrm{CO}$. In spite of the fact that his condensed phase compositions were not well defined, the results seen in fig. 2 are in reasonable agreement with the equilibrium values.

3.3 Phase Field $\mathrm{PuO}_{1.5}+\mathrm{PuC}_{1.5}+\mathrm{C}$

The computed partial pressures for the species over the $\mathrm{PuO}_{1.5}+$ $P M C_{1 . b}+C$ phase field are also shown in fig. 2. Igain Pottcr'o [5] calculated equilibrium $\mathrm{p}_{\mathrm{CO}}$ values correspond closely to those given here. Partial pressures of $\mathrm{CO}$, measured by Pascard and Roullet and reported by Potter [5], are a factor of 4 greater than those calculated in the present study. Pickles [18], gives CO partial pressures for this region at $\mathrm{T}>$ $1770 \mathrm{~K}$ found during the carbothermic reduction of the oxide. His results are as much as a factor of 7 higher than the calculated equilibrium pressures. It is possible that a small amount of the nonequilibrium phase 


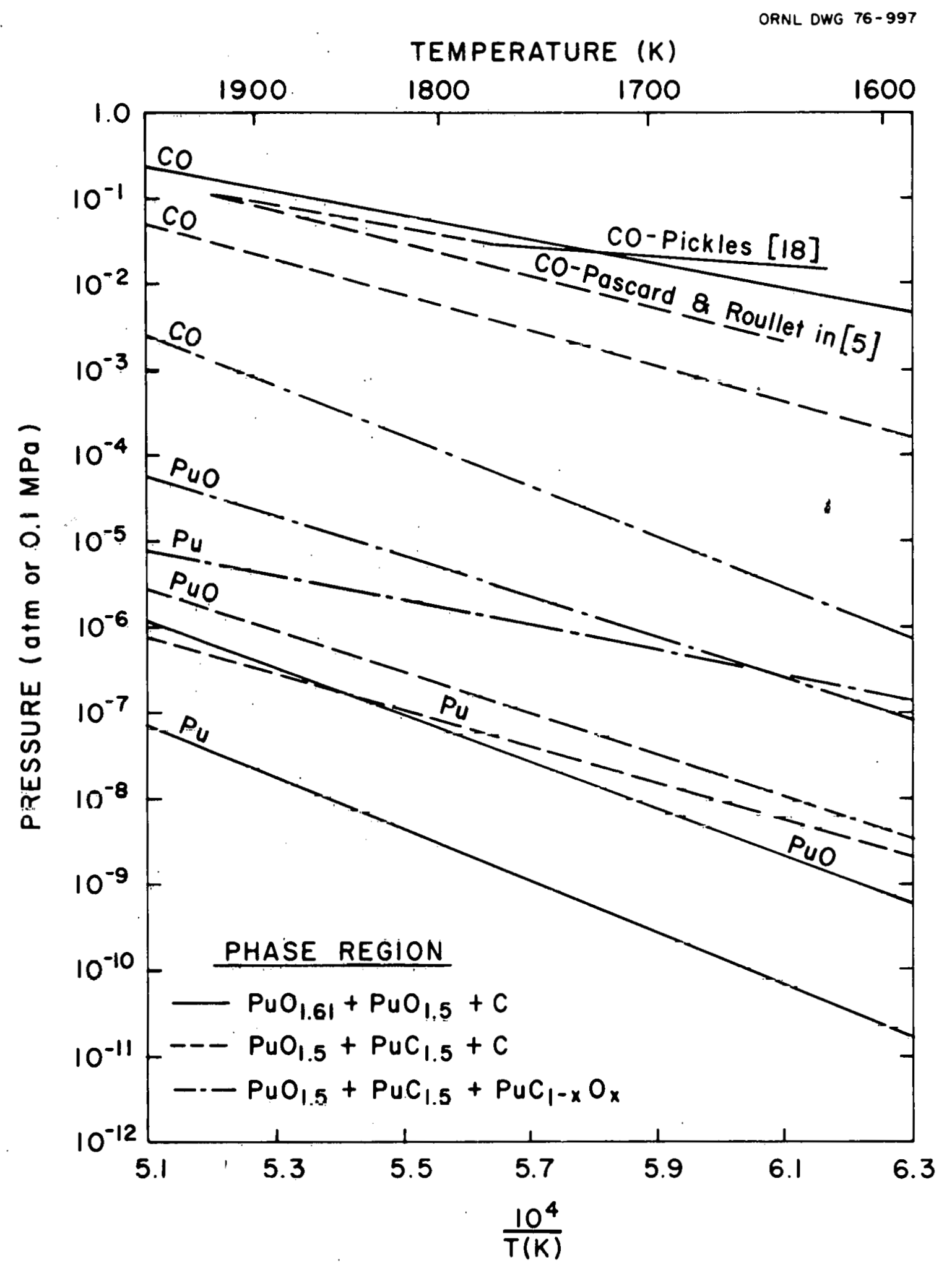

Fig. 2. Calculated equilibrium partial pressures of $\mathrm{CO}, \mathrm{Pu}$, and $\mathrm{PuO}$ and Pascard and Roulett's [5] and Pickles [18] measured CO partial pressures over regions of the $\mathrm{Pu}-\mathrm{C}-\mathrm{O}$ phase diagram versus reciprocal temperature. 
$\mathrm{PuO}_{2-\mathrm{x}}$, where $\mathrm{x} \leq 0.39$, was present in his samples, prevented the system from equilibrating, and yielded the higher pressure.

3.4 Fhase Field $\mathrm{PuO}_{1.5}+\mathrm{PuC}_{1-\mathrm{x}} \mathrm{O}_{\mathrm{x}}+\mathrm{PuC}_{1.5}$

The computation of reliable equilibrium partial pressures above the three-phase region bounded by sesquicarbide, monoxycarbide, and sesquioxide is hindered by a lack of thermodynamic data for the monoxycarbide. Potter [5], in order to perform equilibrium calculations, assumed that plutonium monoxycarbide was a solid solution of PuO and PuC and used both the ideal and regular solution models. In light of the recently assessed thermodynamic values for the plutonium carbides [16], the ideal solution model described below appears most appropriate and is used in the present study.

The monoxide of plutonium is not a stable phase, and thus in order to utilize the ideal solution model, an expression for the molar free energy of Puo must be derived. Potter [5] notes that the partial molar free energy can be determined from the three-phase region containing liquid plutonium, $\mathrm{PuO}_{1.5}$, and $\mathrm{PuC}_{0.27^{\circ}} 0.67$ shown in fig. 1 . The chemical reaction

$$
\{\mathrm{Pu}\}+2<\mathrm{PuO}_{1.5}>=3\left[\mathrm{PuO}_{\mathrm{PuC}}\right.
$$

would thus exhibit a $\Delta G_{r \times n}^{O}=0$ at equilibrium and, therefore,

$$
\Delta \bar{G}_{f[\mathrm{PuO}]}=2 / 3 \Delta \mathrm{G}_{\mathrm{f}}^{\circ}<\mathrm{PuO}>+\mathrm{RT} \ln \mathrm{x}
$$

where $\mathrm{x}$ is the mol fraction of Puo present in the solution. Thus at $\mathrm{x}=0.67$

$$
\Delta G_{f<P u O}^{\circ}>=2 / 3 \Delta G_{f}^{O}<P_{1.5}>-R T \text { In } x .
$$


The monocarbide of plutonium only exists at $\mathrm{C} / \mathrm{Pu}$ ratios less than 1.0 and detailed thermodynamic data is reported for $\mathrm{PuC}_{0.88}$ [16]. It is this phase which is assumed to dissolve PuO to form the solid solution. For simplicity, however, the solid solution is written $\mathrm{PuC}_{1-\mathrm{x}} \mathrm{O}_{\mathrm{x}}$. The partial molar free energy for the dissolved monocarbide is expressed as

$$
\Delta \bar{G}_{f[P u C]}=\Delta G_{f<P u C_{0.88}^{\circ}}^{\circ}+R T \text { In }(1-x)
$$

The equilibrium between $\mathrm{PuC}_{1.5}$, Pur. ${ }_{1-\mathrm{x}} \mathrm{O}_{\mathrm{x}}$, and PuO ${ }_{1.5}$ permits the reaction

$$
3[\mathrm{PuO}]+2<\mathrm{PuC}_{1.5}>=3[\mathrm{PuC}]_{\mathrm{PuO}}+2<\mathrm{PuO}_{1.5}>
$$

to have a $\Delta G_{\text {rxn }}^{\circ}=0$. 'Ihis reaction can be used with expressions of the free energies given above to derive, as a function of temperature, the mol fraction of [PuO] in the solid solution. The results are plotted in fig. 3 as $x$ versus temperature.

The validity of the ideal solution model described above is strengthened by the experimental results of Brett et al. [19] and Potter [3]. Brett et al. at $1773 \mathrm{~K}$ determined that $\mathrm{x}=0.34$, and, at $15^{\prime} 73 \mathrm{~K}$, rotter found that $\mathrm{x}=0.38$. These are almost identical to the predicted values plotted in fig. 3.

The ideal solution model in the form of eqs. (1), (2), and (3) was used to find $\Delta \bar{G}_{f}$ for $[\mathrm{PuO}]_{\mathrm{PuC}}$ and $[\mathrm{PuC}]_{\mathrm{PuO}}$ as a function of $\mathrm{x}$. These values were used to compute the equilibrium partial pressures above the condensed phase region $\mathrm{PuC}_{1.5}+\mathrm{PuC}_{1-\mathrm{x}} \mathrm{O}_{\mathrm{x}}+\mathrm{PuC}_{1.5}$ which are plotted in fig. 2. Pottcr [5] reports calculaten, equilibrium 60 pressures derived both from ideal and regular solution models. The results of his ideal solution calculations agree reasonabiy with the $p_{C O}$ values reported in the present study. 


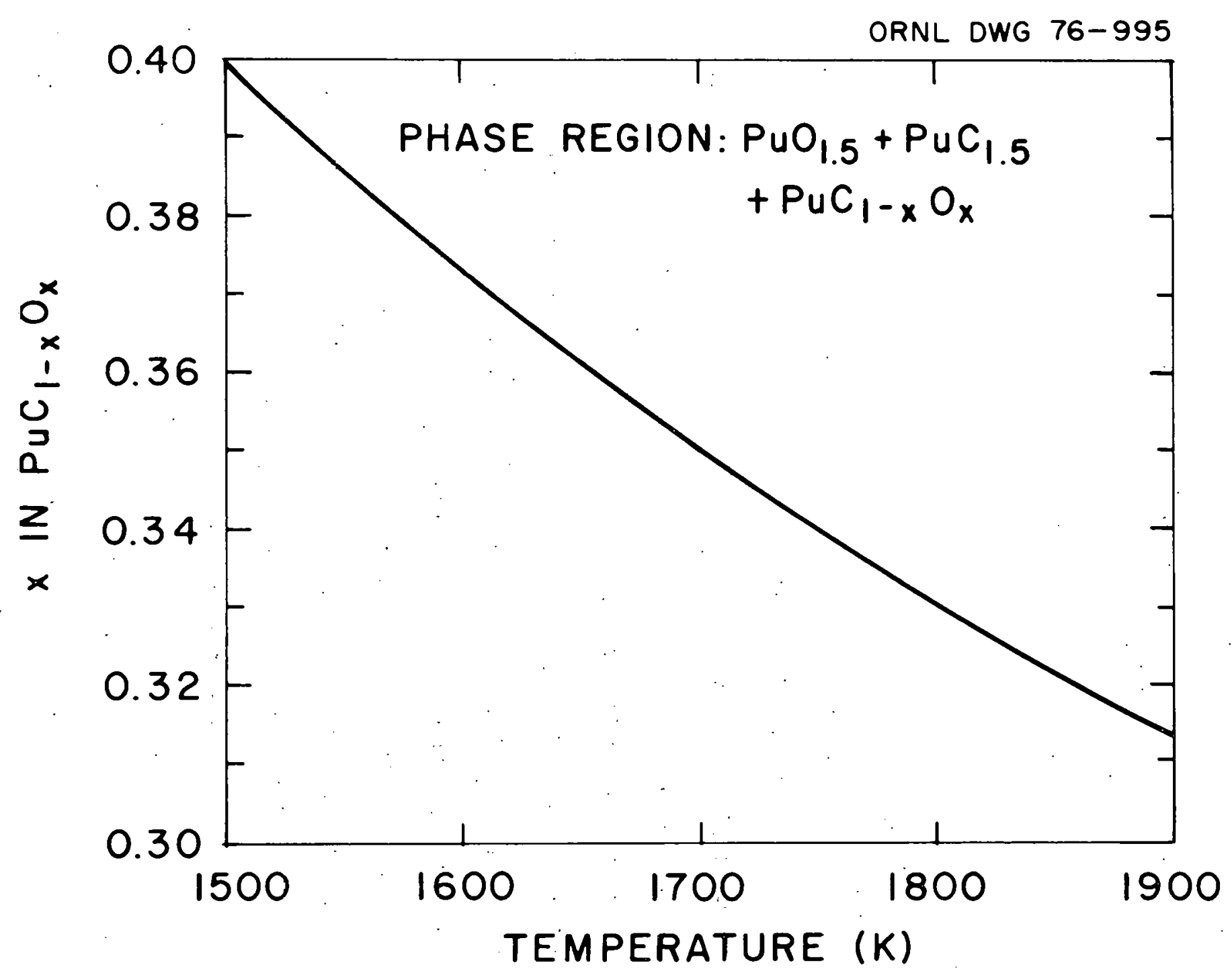

Fig. 3. Mol fraction of $\mathrm{PuO}$ in the solid solution $\mathrm{PuC}_{1-\mathrm{x}} \mathrm{O}_{\mathrm{x}}$ in equilibrium with $\mathrm{PuC}_{1.5}+\mathrm{PuO}_{1.5}$ versus temperature. 


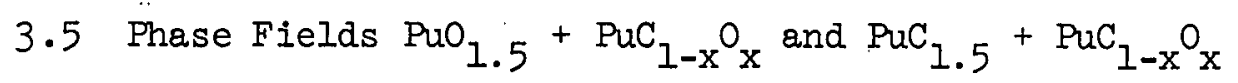

Equations (1), (2), and (3) were also used to calculate the equilibrium partial pressures of the various species over $\mathrm{PuO}_{1.5}+\mathrm{PuC}_{1-\mathrm{x}} \mathrm{O}_{\mathrm{x}}$ and $\mathrm{PuC}_{1.5}+\mathrm{PuC}_{1-\mathrm{x}} \mathrm{O}_{\mathrm{x}}$. The partial pressures of $\mathrm{CO}, \mathrm{Pu}$, and PuO versus $\mathrm{x}$ are plotted in fig. 4 for 1600 and $1900 \mathrm{~K}$. It is important to note that $\mathrm{p}_{\mathrm{CO}}$ becomes less than $\mathrm{p}_{\mathrm{Pu}}$ as $\mathrm{x} \rightarrow 0$ and as $\mathrm{x} \rightarrow 0.67$. It is also observed that lower temperatures favor a larger compositional region over which $\mathrm{p}_{\mathrm{CO}}<\mathrm{p}_{\mathrm{Pu}}$

Using a regular solution model, Potter [5] has calculated a set of curves for $1600 \mathrm{~K}$ (incorrectly reported as being for $1500 \mathrm{~K}$ in his fig. 11) similar to those in fig. 4 for the partial pressures of $\mathrm{CO}, \mathrm{Pu}, \mathrm{PuO}$, and $\mathrm{PuO}_{2}$. Reasonable agreement is found for the equilibrium partial pressures above the phase fields.

Some vacuum vaporization experiments with the monoxycarbide have been performed by Potter [3]. He reported that in the range 1598-1723 K the $\mathrm{PuC}_{0.5} \mathrm{O}_{0.5}$ phase appears to vaporize congruent $1 \mathrm{~V}$. This agrees with the results of the equilibrium calculations shown in fig. 4, i.e., $p_{\text {CO }}=$ $\mathrm{p}_{\mathrm{Pu}}$ at $\mathrm{x} \cong 0.5$. Using the Langmuir free evaporation relation with the assumptions of minimum surface area for vaporization (surface of a sphere) and no kinetic limitations on evaporation, Potter found plutonium partial pressures at several temperatures. The results of his calculations are, however, one order of magnitude too great due to an arithmetic error in the third equation in his Section 6.2. The correct values between 1598 and $1723 \mathrm{~K}$ are between $2.18 \times 10^{-7}$ and $2.13 \times 10^{-6} \mathrm{~atm}(0.0221$ and 0.216 $\mathrm{Pa})$, respectively. These are in good agreement with the equilibrium values shown in fig. 4. 


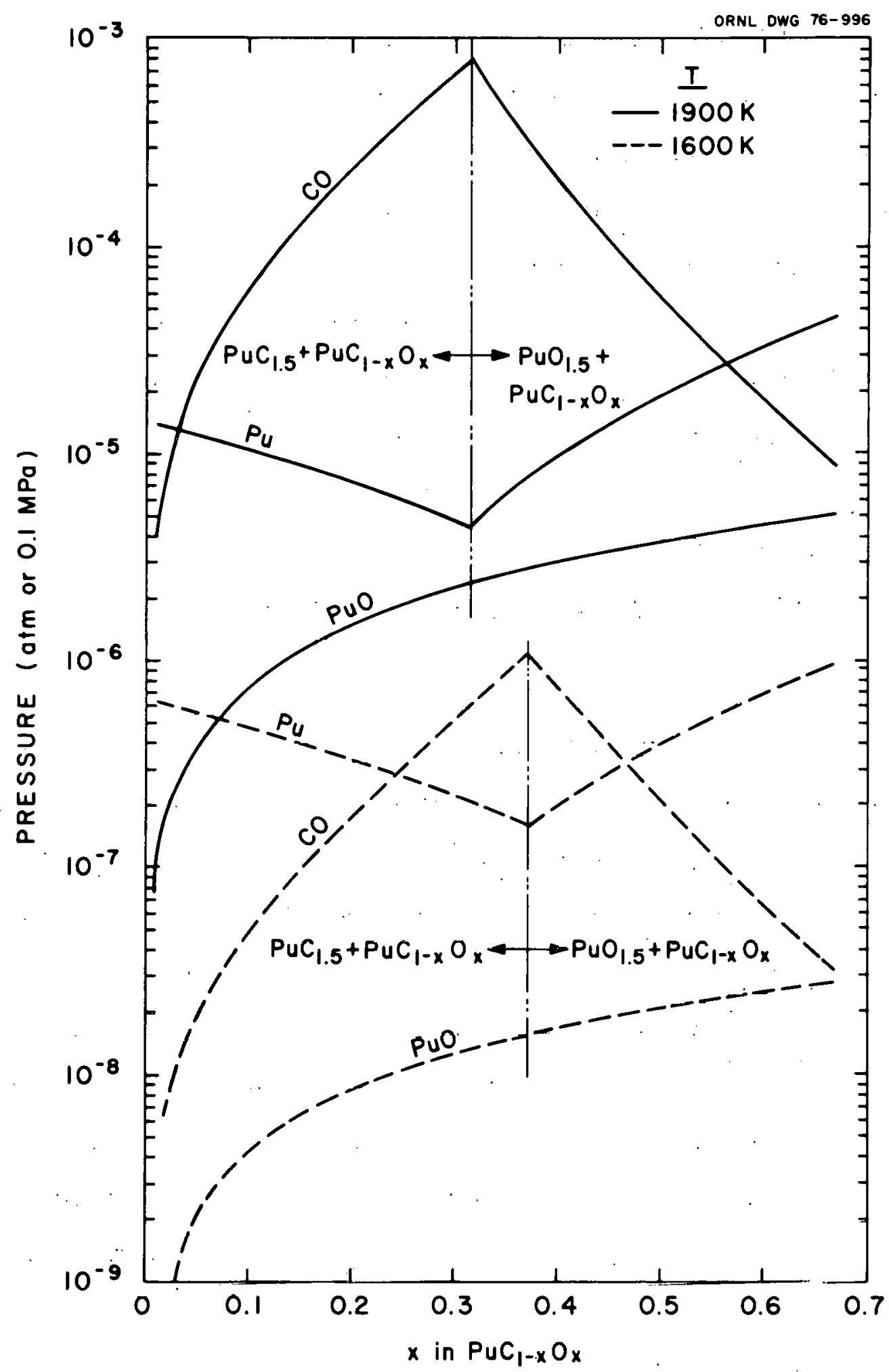

Fig. 4. Calculated equilibrium partial pressures of $\mathrm{CO}, \mathrm{Pu}$, and $\mathrm{PuO}$ at $1600 \mathrm{~K}$ and $1900 \mathrm{~K}$ above the idea.l. solid solution $\mathrm{PuC}_{1-\mathrm{x}} \mathrm{O}_{\mathrm{xr}}$, present with $\mathrm{PuO}_{1.5}$ or $\mathrm{PuC}_{1.5}$, versus $\mathrm{x}$. 
Yahata and Ouchi [4] report preparing mixtures of $\mathrm{PuC}_{1-\mathrm{x}}$ and $\mathrm{PuC}_{1.5}$ by the direct carbothermic reduction of the oxide in vacuum over the temperature range $1273-1623 \mathrm{~K}$. Unfortunately, they do not appear to have considered the possible retention of oxygen by the monocarbide and did not analyze for oxygen. They report a lattice parameter for the moniocarbide of $0.4978 \mathrm{~nm}$ which, according to Potter [5], indicates a phase composition of $\mathrm{PuC}_{0.87^{\circ}} \mathrm{O} .13^{\circ}$ Additionally, the thermodymamic equilibrium calculations presented here indicate that at a composition of approximately $\mathrm{PuC}_{0.8^{\mathrm{O}} \mathrm{O} .2,} \mathrm{P}_{\mathrm{CO}}=\mathrm{p}_{\mathrm{Pu}}$ and continued reduction of the monoxycarbide becomes impossible. Thus it is likely that Yahata and Ouchi [4] prepared a monocarbide containing a significant quant1ty of oxygen which they did not detect.

4. Assessment of Direct Carbothermic Reduction

The results of both the thermodynamic equilibrium calculations performed by Potter [5] and those of the present study indicates that it is not possible to prepare relatively oxygen-free plutonium monocarbide, under equilibrium conditions, by the direct carbothermic reduction of the oxide. In the reduction process, a monoxycarbide solid solution phase forms which cannot be completely reduced to the monocarbide. Assuming that $\mathrm{PuC}_{1-\mathrm{x}} \mathrm{O}_{\mathrm{x}}$ initially forms in the presence of $\mathrm{PuC}_{1.5}$ and $\mathrm{PuO}_{1.5}$, it can be seen from fig. 4 that as $x$ decreases, $p_{C O}$ will decrease and $p_{P u}$ will increase. Eventually, $p_{C O}$ approaches $p_{P u}$, effectively preventing the continued reduction of the phase.

From fig. 4, it can be seen that in the presence of $\mathrm{PuC}_{1.5}$, as temperature increases, the value of $\mathrm{x}$ at which $\mathrm{p}_{\mathrm{CO}}=\mathrm{p}_{\mathrm{Pu}}$ decreases. Thus it might 
be expected that at high enough temperatures $\ddot{p}_{\mathrm{CO}}$ remains significantly greater than $p_{P u}$ to very low values of $x(<0.001)$; permitting the efficient carbothermic reduction to $\mathrm{PuC}_{1-\mathrm{x}}$. Unfortunately, plutonium monocarbide decomposes peritectically at $1918 \mathrm{~K}$ [20]. A reduction procèss carried out much above $1900 \mathrm{~K}$ would, therefore, result in the formation of a liquid plutonium phase which would be undesirable due to the high volatility and chemical reactivity of the liquid.

The results of attempts to carbothermically reduce the oxide to the monocarbide appear to confirm the implications of the thermodynamic equilibrium calculations. Skavdahl's [2] efforts to prepare oxygen-free PuC ${ }_{1-x}$ by the carbothermic reduction of $\mathrm{PuO}_{2}$ both in 1 atm ( $\left.0.1 \mathrm{MPa}\right)$ of inert gas and in vacuum were unsuccessful. Mulford et al. [21] and Potter [3.] report a congruently vaporizing $\mathrm{PuC}_{1-\mathrm{x}} \mathrm{O}_{\mathrm{x}}$ composition that prevents the formation of the monocarbide. Yahata and Ouchi [4], as noted earlier, probably only formed the monoxycarbide in attempts to prepare $\mathrm{PuC}_{1-\mathrm{x}}$. Ainsley et al. [1] heated pellets of $\mathrm{PuO}_{2}-\mathrm{C}$ mixtures in vacuum for $50 \mathrm{~min}$ at $1943 \mathrm{~K}$, which is above the peritectic decomposition temperature for $\mathrm{PuC}_{1-\mathrm{x}}$. They report the product as plutonium monocarbide containing a minor amount of sesquicarbide. A plutonium loss of $1.54 \%$ was also observed.

At present the only chemical kinetic study of the carbothermic reduction of $\mathrm{PuO}_{2}$ has been that of Yahata and Ouchi [4]. They observed that pellets which originally had a $\mathrm{C} / 0$ ratio of 1.45 , when heated in vacuum reacted initially at a low rate and produced a so-called transient stable phase. Increasing the reaction temperature, however, reduced the length of time at this low rate such that the step essentially disappears at $T \geq 1600 \mathrm{~K}$. They noted that the conversion rates follow those expected 
for the decreasing reacting surface area of spherical particles. This indicates that the process is rate-controlled by solid-state mechanisms over the temperature range studied, $1273-1623 \mathrm{~K}$. An apparent activation energy of $102 \mathrm{kcal} / \mathrm{mol}(427 \mathrm{~kJ} / \mathrm{mol})$ was derived for the process.

\section{Assessment of Two-Step Reduction}

A possibly attractive alternative to the direct carbothermic reduction of $\mathrm{PuO}_{2}$ to $\mathrm{PuC}_{1-\mathrm{x}}$ is a two-step reduction process that has been successfully used by Sowden et al. [6]. The primary overall reaction for each step is :

$\left.<\mathrm{PuO}_{2}>+3.5<\mathrm{C}\right\rangle=\left\langle\mathrm{PuC}_{1.5}\right\rangle+2(\mathrm{CO})$

$<\mathrm{PuC}_{1,5}>+(2 \mathrm{x}+1)\left(\mathrm{H}_{2}\right)=\left\langle\mathrm{PuC}_{1-\mathrm{x}}>+(\mathrm{x}+0.5)\left(\mathrm{CH}_{4}\right)\right.$.

Weber and Greenhalgh [22] have devised a similar multistep process for preparing nitride nuclear fuels in which free carbon is removed by reaction with hyarogen.

The first step in the two-step process is the carbothermic reduction of the oxide to $\mathrm{PuC}_{1.5}$ in vacuum or flowing inert gas. It is expected that the use of excess carbon will prevent the formation of the ternary solid solution $\mathrm{PuC}_{1-\mathrm{x}} \mathrm{O}_{\mathrm{x}}$, and thus avoid the problem of significant plutonium vaporization. Ainsley et al. [1], Potter [3], and Yahata and ouch1 [4] report successfully preparing $\mathrm{PuC}_{1.5}$ in vacuum, and Ainsley et al. [1] indicate a plutonium loss of only $0.036 \%$.

The regions of the Pu-C-O phase diagram, fig. 1, which must be considered in converting the oxide to the sesquicarbide are $\mathrm{PuO}_{2-\mathrm{x}}+\mathrm{C}$ $(0.0 \leq x \leq 0.39), \mathrm{PuO}_{1.61}+\mathrm{PuO}_{1.5}+\mathrm{C}$, and $\mathrm{PuO}_{1.5}+\mathrm{PuC}_{1.5}+\mathrm{C}$. The reactions are: 


$$
\begin{aligned}
& <\mathrm{PuO}_{2-\mathrm{x}}>+(0.39-\mathrm{x})<\mathrm{C}>=\left\langle\mathrm{PuO}_{1.61}>+(0.39-\mathrm{x})(\mathrm{CO})\right. \\
& <\mathrm{PuO}_{1.61}>+0.11<\mathrm{C}>=<\mathrm{PuO}_{1.5}>+0.11(\mathrm{CO})
\end{aligned}
$$

and

$$
<\mathrm{PuO}_{1.5}>+3<\mathrm{C}>=<\mathrm{PuC}_{1.5}>+1.5(\mathrm{CO}) .
$$

Again, at temperatures greater than $1600 \mathrm{~K}$, the equilibrium 60 partial pressure above $\mathrm{PuO}_{2-\mathrm{x}}+\mathrm{C}$ is greater than 0.02 atm $(0.002 \mathrm{MPa})$, and, therefore, is not considered as limiting the reduction process. The equilibrium partial pressures above the remaining phase fields are shown in fig. 2.

A likely conversion process would use a stream of flowing inert gas at $1 \mathrm{~atm}(0.1 \mathrm{MPa})$ in which the oxide is converted to the sesquicarbide. The volume of inert gas required to complete reactions (4), (5), and (6), assuming the condensed phases are in equilibrium with the gas, can be found from

$$
\mathrm{v}=22.4 \frac{\mathrm{Z}}{\mathrm{p}_{\mathrm{CO}}}
$$

where $\mathrm{V}$ is the volume in liters (STP), $\mathrm{Z}$ is the mols of $\mathrm{CO}$ liberated per mol of oxide reduced, and $p_{C O}$ is the equilibrium $c 0$ partial pressure, in atmospheres, in the appropriate phase field. As might be expected, reaction $(6)$ is the limiting reaction since it requires $1.5 \mathrm{mols}$ of $\mathrm{co}$ to be formed per mol of oxide reacted and $\mathrm{p}_{\mathrm{CO}}$ above $\mathrm{PuC}_{1.5}+\mathrm{PuO}_{1.5}+\mathrm{C}$ is small compared to that above the other phase fields. Using the $\mathrm{p}_{\mathrm{CO}}$ values shown in fig. 2, the volume of gas required to convert one mol of $\mathrm{PuO}_{2}$ to $\mathrm{PuC}_{1.5}$ is plotted as a function of temperature in fie. 5.

Figure 5 can be seen to also contain a plot of temperature versus the percent plotonium vaporized from a charge of oxide and carbon reacting to form the sesquicarbide. Interestingly, although the volume of 


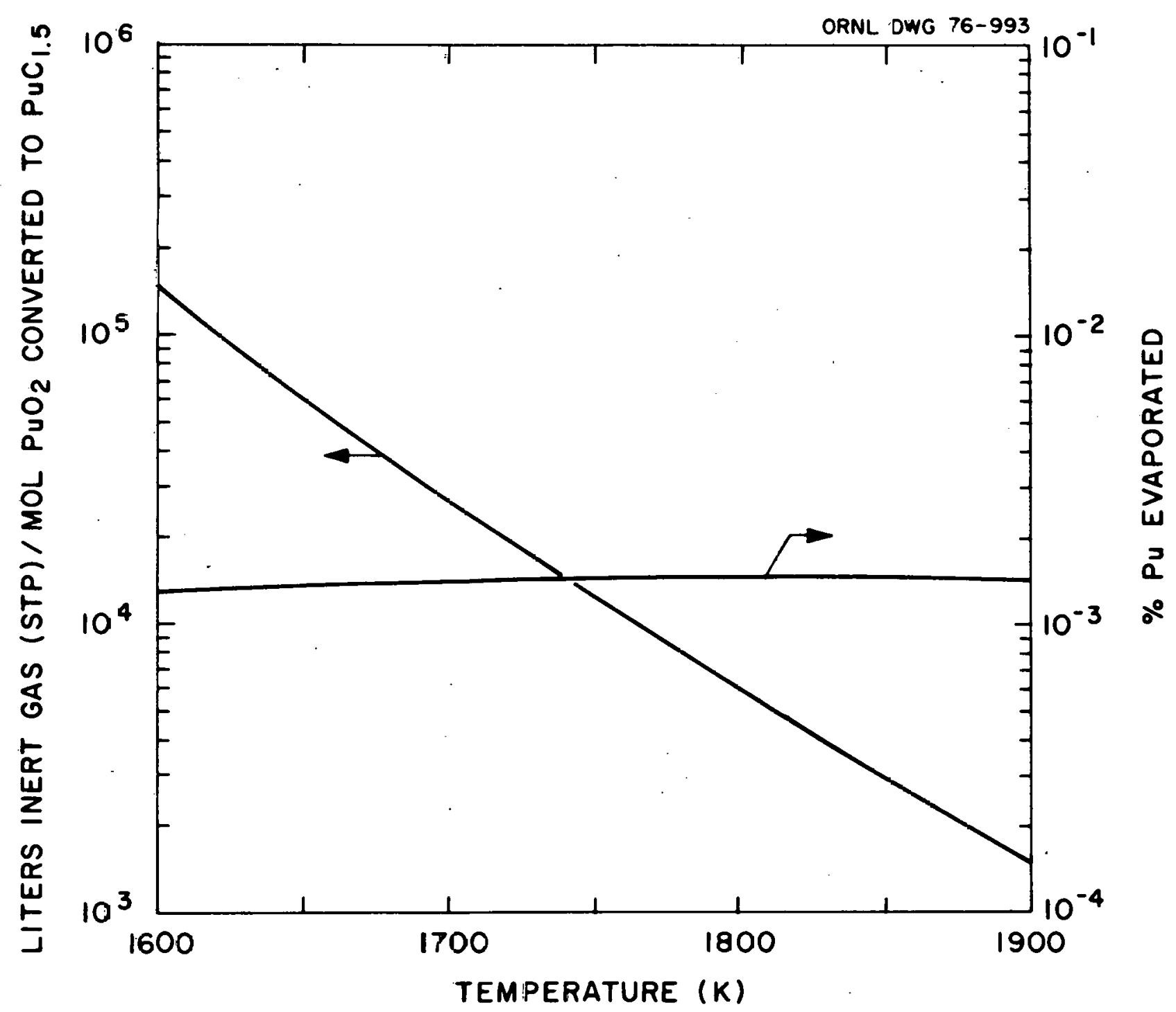

Fig. 5. Liters of inert gas. (STP) required to convert $\mathrm{PuO}_{2}$ to $\mathrm{PuC}_{1.5}$ and the percentage of plutonium vaporized versus temperature. Thermodynamic equilibriam conditions are assumed. 
inert gas required for conversion of $\mathrm{PuO}_{2}$ to $\mathrm{PuC}_{1.5}$ decreases with increasing temperature, the percentage of plutonium vaporized remains relatively constant at $\sim 0.0015 \%$. The percentage remains constant because the partial pressures of $\mathrm{CO}$ and plutonium increase with temperature to maintain an approximately constant ratio, i.e., the reactions forming the two gaseous species have similar $\Delta \mathrm{H}_{\mathrm{rxn}}^{\mathrm{O}}$.

In order to perform an analysis of the hydrogen reduction of $\mathrm{PuC}_{1.5}$ to $\mathrm{PuC}_{1-\mathrm{x}}$ analogous to that described above, the computation of equilibrium partial pressures of the gaseous species in the $\mathrm{Pu}-\mathrm{C}-\mathrm{H}$ system is required. In particular, the partial pressures in hydrogen above the condensed phases $\mathrm{PuC}_{1.5}+\mathrm{PuC}_{0.88}$ must be established. The data in Table 1 were used with the computer program SOLGAS to calculate the equilibrium partial pressures of the species $\mathrm{H}, \mathrm{H}_{2}, \mathrm{CH}_{4}, \mathrm{C}_{2} \mathrm{H}_{2}, \mathrm{Pu}$, and $\mathrm{PuC}_{2}$. The calculations indicated that over the temperature range 1000-1700 $\mathrm{K}$ the only species having significant partial pressures were $\mathrm{H}_{2}, \mathrm{CH}_{4}$, and $\mathrm{Pu}$.

In the hydrogen reduction of $\mathrm{PuC}_{1.5}$ to $\mathrm{PuC}_{0.88}$, caution must be exercised so that the monocarbide is not further reduced to the liquid metal via

$$
<\mathrm{PuC}_{0: 88}>+1.76\left(\mathrm{H}_{2}\right)=\{\mathrm{Pu}\}+0.88\left(\mathrm{CH}_{4}\right)
$$

This can be ensured by adding $\mathrm{CH}_{4}$ to the hydrogen stream so that $\mathrm{p}_{\mathrm{CH}_{4}}$ is maintained greater than the equilibrium value in reaction (8).

Using a relation analogous to eq. (7) the volume of hydrogen required to reduce one mol of $\mathrm{PuC}_{1.5}$ to $\mathrm{PuC}_{0.88}$ was computed and plotted versus temperature in fig. 6. It was assumed that sufficient. $\mathrm{CH}_{4}$ is added to the hydrogen before it contacts the carbide so that $\mathrm{p}_{\mathrm{CH}_{4}}$ in the reactant stream is greater than the equilibrium value for reaction (8). Also plotted as 


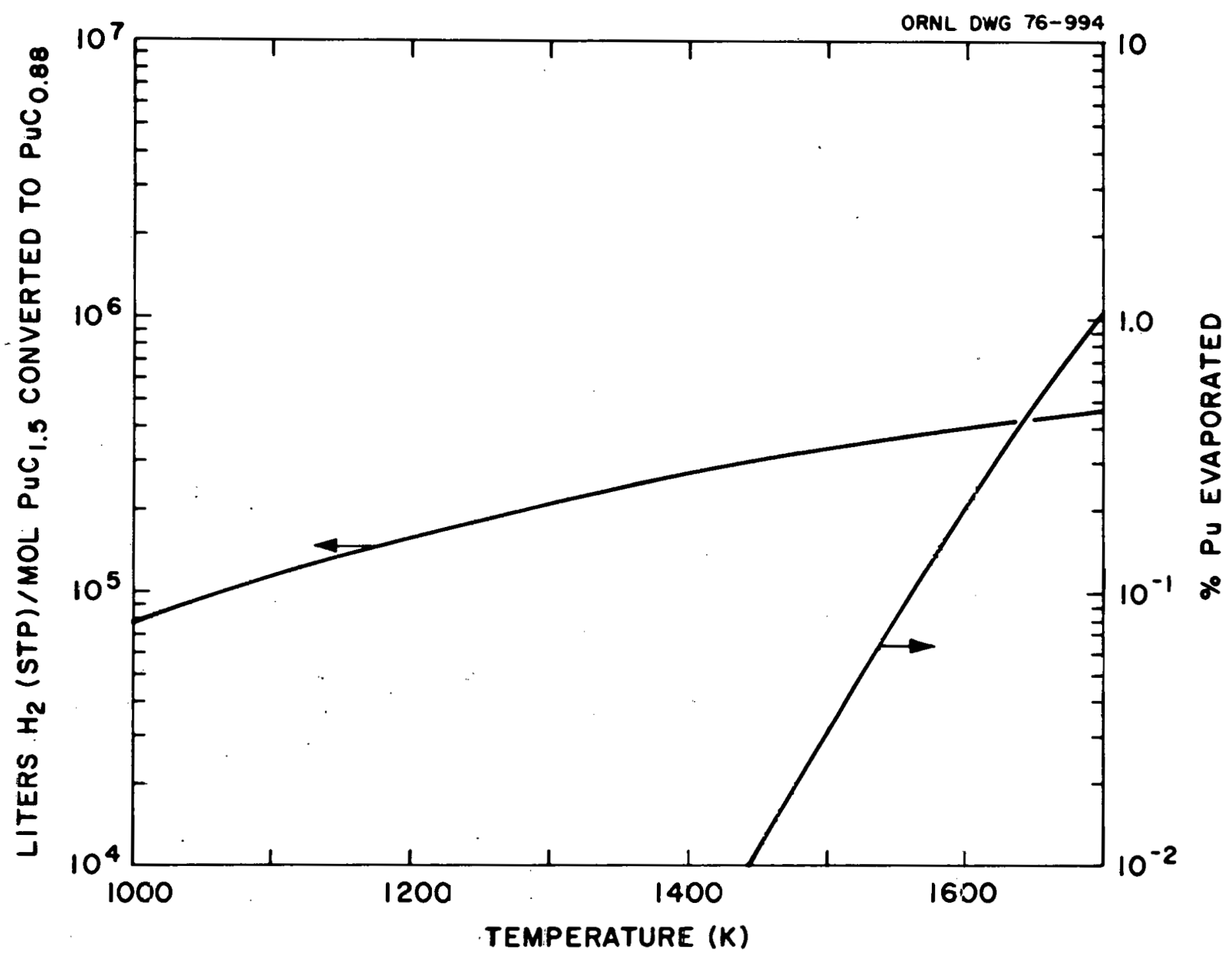

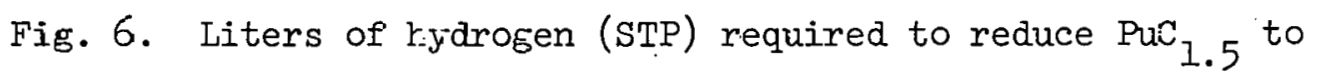
$\exists \mathrm{uC}_{J .88}$ and the percentage of plutonium vaporized versus jemperature. Thermodynamic equilibriun conditions are assumed. 
a function of temperature in fig. 6 is the percentage of plutonium vaporized during the reduction.

A typical, complete, two-step reduction process might use a 10-g charge of oxide-graphite mixture reacting to $\mathrm{PuC}_{1.5}$ at $1900 \mathrm{~K}$ in a $6 \mathrm{l} / \mathrm{min}$ (STP) inert gas stream. Figure 5 indicates that, at equilibrium, 8 min is required to reduce the oxide with $0.0015 \%$ of the plutonium volatilizing. The subsequent hydrogen reduction at $1300 \mathrm{~K}$ in a $6 \mathrm{l} / \mathrm{min}$ (STP) stream of hydrogen would require $18.6 \mathrm{hrs}$ and volatilize about $0.0003 \%$ of the plutonium.

Sowden et al. [6] have successfully prepared $\mathrm{PuC}_{1-\mathrm{x}}$ by the hydrogen reduction of $\mathrm{PuC}_{1.5^{\circ}}$ The most efficient conversion they report was performed at $1273 \mathrm{~K}$ in a $1 \mathrm{k} / \mathrm{min}(\mathrm{STP}), I$ atm $(0.1 \mathrm{MPa}) \mathrm{H}_{2}$ stream. The powdered $0.25-\mathrm{g}$ PuC $_{1.5}$ sample had a $1.8-\mathrm{m}^{2} / \mathrm{g}$ surface area and required $6 \mathrm{hrs}$ for complete conversion. The results are in contrast to the $2.6 \mathrm{hrs}$ conversion time predicted for these conditions from equilibrium calculations (fig. 6). The discrepancy in conversion time is most likely due to rate-limiting effects preventing the attainment of equilibrium between the gas and the condensed phases. It should be noted that even if one assumed that the system were at equilibrium for $6 . \mathrm{hrs}$, the predicted plutonium loss would only be approximately $0.0002 \%$.

\section{Conclusions}

1. The thermal properties of plutonium monoxycarbide can be successfully modeled by assuming the phase is an ideal solld solution of $\mathrm{PuC}_{0.88}$ and PuO. 
2. Both the results of our equilibrium thermodynamic calculations and the experiments of others indicate that $\mathrm{PuC}_{1-\mathrm{X}}$ cannot practically be prepared by the carbothermic reduction of $\mathrm{PuO}_{2}$. During the reduction process, the ternary solid solution $\mathrm{PuC}_{1-\mathrm{x}} \mathrm{O}_{\mathrm{x}}$ forms and under equilibrium conditions, as $\mathrm{x}$ decreases, $\mathrm{p}_{\mathrm{CO}} \rightarrow \mathrm{p}_{\mathrm{Pu}}$ and prevents the phase composition from approarhing that of the monocarbide.

3. Carbothermic reduction of $\mathrm{PuO}_{2}$ at temperatures greater than the peritectic decomposition temperature of $\mathrm{PuC}_{1-x}$ may remove essentially all the oxygen from the system. However, the resulting tormation of liquid plutonium would be undesirable.

4. Calculations indicate that the two-step reduction of $\mathrm{PuO}_{2}$ to $\mathrm{PuC}_{1-\mathrm{x}}$ appears feasible and will minimize plutonium logs. Sarhothermic reduction with an excess of carbon can produce $\mathrm{PuC}_{1.5}$ from the oxide and avoid the ternary solid solution phase $\left(\mathrm{PuC}_{1-\mathrm{x}} \mathrm{O}_{\mathrm{x}}\right)$. The cesquicarbine could then he reduced by hydrogen to $\mathrm{PuC}_{1-\mathrm{X}}{ }^{*}$

\section{Acknowledgments}

The authors are grateful to Karl E. Spear of the Pennsylvania State University, Edward C. Beahm of the Oak Ridge National Laboratory, and Paul E. Potter of the AERE, Harwell for valuable discussions and suggestions. Betty Drake and Catherine Shappert provided valuable assistance with manuscript preparation. 
Appendix

Calculated Equilibrium Partial Pressures (atm)*

1. Phase Region: $\left\langle\mathrm{PuO}_{1.61}\right\rangle+\left\langle\mathrm{PuO}_{1.5}\right\rangle+\langle\mathrm{C}\rangle$

$\ln \mathrm{p}_{\mathrm{CO}}=-\frac{32600}{\mathrm{~T}}+15.2$

In $\mathrm{p}_{\mathrm{Pu}}=-\frac{69900}{\mathrm{~T}}+19.2$

In $\mathrm{p}_{\mathrm{PuO}}=-\frac{62900}{\mathrm{~T}}+18.4$

2. Phase Region: $\left\langle\mathrm{PuC}_{1.5}\right\rangle+\left\langle\mathrm{PuO}_{1.5}\right\rangle+\langle\mathrm{C}\rangle$

$\ln \mathrm{p}_{\mathrm{CO}}=-\frac{46300}{\mathrm{~T}}+20.5$

In $\mathrm{p}_{\mathrm{Pu}}=-\frac{48200}{\mathrm{~T}}+10.5$

In $\mathrm{p}_{\mathrm{PuO}}=-\frac{56000}{\mathrm{~T}}+15.7$

3. Phase Region: $\left\langle\mathrm{PuC}_{1.5}\right\rangle+\left\langle\mathrm{PuC}_{1-\mathrm{x}_{\mathrm{x}} \mathrm{O}}\right\rangle+\left\langle\mathrm{PuO}_{1.5}\right\rangle$

$\ln \mathrm{p}_{\mathrm{CO}}=-\frac{72900}{\mathrm{~T}}+30.2+\ln \mathrm{x}-5 \ln (1-\mathrm{x})$

$\ln p_{P u}=-\frac{31300}{T}+5.32+3 \ln (1-x)$

ln $\mathrm{p}_{\mathrm{PuO}}=-\frac{52800}{1^{\prime}}+16.0=\ln \mathrm{x}$

4. Phase Region: $\left\langle\mathrm{PuO}_{1.5}>+<\mathrm{PuC}_{1-\mathrm{x}^{\mathrm{O}} \mathrm{O}}\right\rangle$

$\ln \mathrm{p}_{\mathrm{CO}}=-\frac{56900}{\mathrm{~T}}+17.4+\ln (1-\mathrm{x})-5 \ln \mathrm{x}$

In $\mathrm{p}_{\mathrm{Pu}}=-\frac{39300}{\mathrm{~T}}+11.9+3 \ln \mathrm{x}$

In $\mathrm{p}_{\mathrm{PuO}}=-\frac{52800}{\mathrm{~T}}+16.0+\ln \mathrm{x}$

* To find the partial pressures in MPa subtract 2.29 from each equation. 
5. Phase Region: $\left\langle\mathrm{PuC}_{1.5}\right\rangle+\left\langle\mathrm{PuC}_{1-\mathrm{x}} \mathrm{O}_{\mathrm{x}}\right\rangle$

$\ln p_{\mathrm{CO}}=-\frac{72900}{\mathrm{~T}}+30.5+\ln \mathrm{x}-5 \ln (1-\mathrm{x})$

In $\mathrm{p}_{\mathrm{Pu}}=-\frac{31300}{\mathrm{~T}}+5.31+3 \ln (1-\mathrm{x})$

$\ln \mathrm{p}_{\mathrm{PuO}}=-\frac{52800}{\mathrm{~T}}+16.0+\ln \mathrm{x}$

6. Phase Region: $<\mathrm{PuC}_{1.5}>+<\mathrm{PuC}_{0.88}>$ in hydrogen

In $\mathrm{p}_{\mathrm{CH}_{4}}=\frac{4230}{\mathrm{~T}}-12.0+\because \ln \mathrm{p}_{\mathrm{H}_{2}}$.

In $\mathrm{p}_{\mathrm{Pu}}=-\frac{39,800}{\mathrm{~T}}+8.69$

7. Phase Region: $<\mathrm{PuC}_{0.88}>+\{\mathrm{Pu}\}$ in hydrogen

In $\mathrm{p}_{\mathrm{CH}_{4}}=\frac{3630}{\mathrm{~T}}-13.2+\ddot{2}$ In $\mathrm{p}_{\mathrm{H}_{2}}$ 
References

[I] R. Ainsley, D. C. Wood, and R. G. Sowden, Proc. Symposium on Carbides in Nuclear Energy, Harwel1, Vol. 2 (November 1963) 540.

[2] R. E. Skavdahl, Hanford Report, HW-77906 (1973).

[3] P. E. Potter, Proc. Symposium on the Thermodynamics of Nuclear Materials, 1967, Vienna (September 1967) 334.

[4] T. Yahata and K. Ouchi, J. Nucl. Sci. Tech. 12 (1975) 115.

[5] P. E. Potter, J. Nucl. Mater. 42 (1972) 1.

[6] R. G. Sowden, N. Hodge, M. J. Moreton-Smith, and D. B. White, Proc. Symposium on Carbides in Nuclear Energy, Harwell, Vol. I (November 1963) 297.

[7] C. E. Holley, J. Nucl. Mater. 51 (1974) 36.

[8] A. Pialoụx and M. Dodé, J. Nucl. Mater. 56 (1975) 221.

[9] G. Eriksson, Acta Chem. Scand. 25 (1971) 2651.

[10] D. R. Stull and H. Prophet (eds.), JANAF Thermochemical Tables, Second Edition (U.S. Government Printing Office, Washington, 1971).

[11] R. Hultgren, P. D. Desai, D. F. Hawkins, M. Gleiser, K. K. Kelley, and D. D. Wagman, Selected Values of the Thermodynamic Properties of the Elements (American Society for Metals, Metals Park, Ohio, 1973).

[12] F. L. Oetting, M. H. Rand, and R. J. Ackerman, The Chemical Thermodynamics of Actinide Elements and Compounds. Part I. The Actinide Elements (IAFA, Vienna, 1976).

[13] R. J. Ackerman and M. S. Chandrasekhariah, Proc. Symposium on the Thermodynamics of Nuclear Materials, 1.974, Vienna, Vol. 2 (October 1974) 3 . 
[14] R. L. Faircloth, R. H. Flowers, and F. C. W. Pummery, J. Inorg. Nucl. Chem. 30 (1968) 499.

[I5] R. H. Schumm, D. D. Wagman, S. Bailey, W. H. Evans, and V. B. Parker, U.S. NBS Technical Note 270-7 (1973).

[16] M. Tetenbaum, A. Sheth, and W. Olson, Argonne Report, ANL-AFP-8 (1975).

[17] T. B. Lindemer and R. A. Bradley, J. Nucl. Mater. 41 (1971) 293.

[18] s. Pickles, Chem. Eng. Progr. Symp. Ser. No. 63 (1967) 64.

[19] N. H. Brett, E. A. Harper, H. J. Hedger, and J. S. Pottinger, proc. Symposium on Carbides in Nuclear Linergy, Harwell, Vol. I (November 1963) 162.

[20] C. E. Holley and E. K. Storms, Proc. Symposium on the Thermodynamics of Nuclear Materials, 1967, Vienna (September 1967) 397.

[21] R. N. R. Mulford, F. H. Ellinger, and K. A. Johnson, J. Nucl: Mater. 17 (1965) 321.

[22] E. T. Weber and W. O. Greenhalgh, U.S. Patent 3,510,434 (1970). 
ORNL/TM-5510

INTERNAL DISTRIBUTION

$\begin{aligned} \text { 1. } & \text { C. F. Baes } \\ \text { 2. } & \text { E. C. Beahm } \\ \text { 3-10. } & \text { T. M. Besmann } \\ \text { 11. } & \text { K. B. Brown } \\ \text { 12. } & \text { C. F. Coleman } \\ \text { 13. } & \text { F. L. Culler } \\ \text { 14. } & \text { D. E. Ferguson } \\ \text { 15. } & \text { J. I. Federer } \\ \text { 16. } & \text { W. J. Lackey } \\ \text { 17. } & \text { J. M. Leitnaker } \\ \text { 18-24. } & \text { T. B. Lindemer } \\ \text { 25-29. } & \text { A. P. Malinauskas } \\ \text { 30. } & \text { H. Postma }\end{aligned}$

31. C. H. Shappert

32. V. J. Tennery

33. D. B. Trauger

34. R. G. Wymer

35-36. Central Research Library

37. Document Reference Section

38. Laboratory Records, ORNL-RC

39-48. Laboratory Records

49. W. K. Davis (consultant)

50. J. C. Frye (consultant)

51. C. H. Ice (consultant)

52. R. B. Richards (consultant)

53. ORNL Patent section

\section{EXTERNAL DISTRIBUTION}

54. Research and Technical Support Division, ERDA-ORO, P. O. Box E, Oak Ridge, TN 37830

55. Director, Reactor Division, ERDA-ORO, P. O. BOX E, Oak Ridge, TN 37830

56-82. Technical Information Center, Oak Ridge, TN 37830

83-84. Director, Division of Reactor Research and Development, U.S. Energy Research and Development Administration, Washington, DC 20545

85. Advanced Fuels Division, U.S. Energy Research and Development Administration, Washington, DC 20545

86. R. P. Epple, Division of Physical Research, U.S. Energy Research and Development Administration, Washington, DC 20545

87. D. K. Stevens, Division of Physical Research, U.S. Energy Research and Development Administration, Washington, DC 20545

88. J. I. Green, Los Alamos Scientific Laboratory, CMB-11, Los Alamos, NM 87544

89. K. W. R. Johnson, Los Alamos Scientific Laboratory, CMB-Il, Los Alamos, NM 87544

90. R. Herbst, Los Alamos Scientific Laboratory, CMB-11, Los Alamos, NM 87544

91. P. D. Shalek, Los Alamos Scientific Laboratory, CMB-11, Los Alamos, NM 8754\%.

92. E. K. Storms, Los Alamos Scientific Laboratory, CMB-11, Los Alamos, NM 87544

93. J. A. Leary, Fuel Systems Branch, RDD, U.S. Energy Research and Development Administration, Germantown, MD 20767

94. J. M. Simmons, Chief, Fuel Systems Branch, RDD, U.S. Energy Research and Development Administration, Germantown, MD 20767

95. R. J. Ackermann, Argonne National Laboratory, 9700 South Cass Avenue, Chicago, IL 60439 